\title{
KKN Covid-19 UNS: Collaboration to Increase Digital Literation for Covid-19 Spreading Awareness
}

\author{
Khresna Bayu Sangka \\ Universitas Sebelas Maret \\ b.sangka@staff.uns.ac.id
}

\section{Article History}

accepted 31/08/2020

approved 22/09/2020

published 28/10/2020

\begin{abstract}
Covid-19 pandemic has affected higher education, the implementation of Real Work Lectures $(K K N)$ is carried out in accordance with government policies, work and school from home. Covid KKN - 19 Universitas Sebelas Maret (UNS) is conducted independently for the environment in which participating students live by utilizing the latest information media. The increase in digital literacy is used as an indicator to measure people's welfare. The series of activities in addition to providing increased digital literacy of citizens regarding the use of social media properly, correctly and wisely also provides increased awareness of the danger of plague. This activity proved to be very successful in terms of participants' participation and enthusiasm. Some key things that became the main points of the success of this collaboration include effective communication between members, collaboration between participants and citizens to understand and protect their families and the surrounding environment, as well as the desire to share the goodness with one another.
\end{abstract}

Keywords: KKN Covid-19, Collaboration, Digital Literacy

\begin{abstract}
Abstrak
Pandemi Covid-19 telah memengaruhi pendidikan tinggi, pelaksanaan Kuliah Kerja Nyata (KKN) dilaksanakan sesuai dengan kebijakan pemerintah, work and school from home. Pelaksanaan KKN Covid - 19 Universitas Sebelas Maret (UNS) dilakukan secara mandiri untuk lingkungan dimana mahasiswa peserta tinggal dengan memanfaatkan berbagai media informasi terkini. Peningkatan literasi digital merupakan tujuan program ini. Rangkaian kegiatan ini selain memberikan peningkatan literasi digital warga mengenai penggunaan sosial media dengan baik, benar dan bijaksana juga memberikan peningkatan kewaspadaan bahaya wabah. Kegiatan ini terbukti berhasil dengan baik dilihat dari partisipasi dan anstusiasme peserta. Beberpa hal kunci yang menjadi poin utama keberhasilan kolaborasi ini antara lain komunikasi yang efektif antar anggota, kolaborasi antar peserta dengan warga untuk saling memahami dan melindungi keluarga dan lingkunan sekitar, serta keinginan untuk saling berbagi kebaikan satu sama lain.
\end{abstract}

Kata kunci: KKN Covid-19, Kolaborasi, Literasi Digital

Social, Humanities, and Education Studies (SHEs): Conference Series https://jurnal.uns.ac.id/shes

p-ISSN 2620-9284

e-ISSN 2620-9292 


\section{PENDAHULUAN}

Pandemi Covid-19 yang telah ditetapkan World Health Organization (WHO) sebagai wabah global telah memengaruhi seluruh sektor kehidupan. Kesehatan, pendidikan, ekonomi, perdagangan, pariwisata, dan lain sebagainya. Efek yang sangat luar biasa bagi perubahan hidup umat manusia. Himbauan dan kebijakan work/school from home sebagai antisipasi penyebaran mengakibatkan banyak peserta didik harus melaksanakan kegiatan belajar di rumah, baik melalui sarana dalam jaringan (daring) maupun luar jaringan (luring). Namun, tidak semua peserta didik maupun pendidik memiliki kemampuan untuk mengakses platform pembelajaran daring secara optimal, begitu juga bagi orang tua wali murid dan masyarakat umum.

Penyebaran informasi yang begitu masif dan tidak terkendali melalui berbagai platform tentu menimbulkan masalah baru yang muncul di masyarakat terutama kurangnya pemahaman masyarakat mengenai virus covid - 19. Masyarakat cenderung kurang peduli dengan adanya pandemic covid - 19 ini. Masyarakat masih belum sadar untuk memakai masker, belum sadar untuk melakukan social dan physical distancing. Masyarakat beranggapan bahwa daerah mereka masih aman, karena belum ada kasus ODP (orang dalam pengawasan), PDP (pasien dalam perawatan), OTG (orang tanpa gejala), atau terkonfirmasi positif covid - 19 di daerah mereka.

Dewasa ini, media sosial telah berubah menjadi media online yang bertujuan mendukung interaksi sosial. Media sosial sebagian besar menggunakan teknologi berbasis web yang mengubah komunikasi menjadi dialog interaktif. (Kaplan \& Haenlein, 2010) mendefinisikan media sosial sebagai "sebuah kelompok aplikasi berbasis internet yang membangun di atas dasar ideologi dan teknologi Web 2.0, dan yang memungkinkan penciptaan dan pertukaran user-generated content". Beberapa situs dan aplikasi media sosial yang populer sekarang ini antara lain: Blog, Twitter, Facebook, Whatsapp, Instagram, dan Wikipedia. Definisi lain dari sosial media juga di jelaskan oleh Van Dijk dan Poell (2013) dimana media sosial merupakan platform media yang memfokuskan pada eksistensi pengguna yang memfasilitasi mereka dalam beraktivitas maupun berkolaborasi. Karena itu, media sosial dapat dilihat sebagai fasilitator online yang menguatkan hubungan antar pengguna sekaligus sebagai sebuah ikatan sosial.

Kolaborasi merupakan salah satu bentuk interaksi sosial. Menurut Abdulsyani, kolaborasi adalah suatu bentuk proses sosial, dimana didalamnya terdapat aktivitas tertentu yang ditujukan untuk mencapai tujuan bersama dengan saling membantu dan saling memahami aktivitas masing-masing (Abdulsyani, 1994). Teori lain mengatakan bahwa kolaborasi berarti bekerja bersama-sama untuk mencapai tujuan bersama. Kolaborasi adalah suatu proses sosial yang paling dasar (Colbry, College, \& Adair, 2014). Biasanya, kolaborasi melibatkan pembagian tugas, dimana setiap orang mengerjakan setiap pekerjaan yang merupakan tanggung jawabnya demi tercapainya tujuan bersama (Roucek \& Warren, 1964),

Media sosial diibaratkan seperti dua mata pisau, artinya media sosial itu dapat memberikan dampak yang positif dan negative (Kaplan \& Haenlein, 2010). Melihat perkembangan penggunaan media sosial online yang didukung oleh kemudahan akses melalui berbagai macam gawai. Kelompok 75 KKN-Covid 19 UNS merasa penting untuk melakukan peningkatan litersi digital warga dengan melakukan berbagai upaya sosialisasi, edukasi, transfer knowledge dan keikutsertaan dalam kegiatan sosial kemasyarakatan dengan mengoptimalkan penggunaan media sosial. Rangkaian kegiatan ini dilakukan secara mandiri sesuai dengan lokasi pelaksanaan KKN dan sesuai dengan kebutuhan yang muncul di lapangan melalui observasi langsung.

\section{METODE}

Metode yang digunakan dalam penelitian pengabdian ini adalah dengan menggunakan pendekatan kualitatif yang disajikan secara deskriptif. Hal ini dilakukan 
selain untuk mendapatkan informasi yang langsung dan dapat dipercaya dari sumbernya, juga merupakan wujud kepedulian dan keikutsertaan mahasiswa dalam penanganan wabah covid-19. Teori yang digunakan dengan menggunakan teori perubahan sosial menggunakan segitiga KAP (Knowledge, Attitude and Practice) dimana dilakukan observasi dan pengamatan langsung mengenai perubahan pengetahuan, pemahaman dan tindakan yang diterima oleh pelaku kegiatan (Muleme, Kankya, Ssempebwa, Mazeri, \& Muwonge, 2017).

\section{HASIL DAN PEMBAHASAN}

Pandemi Covid-19 secara nyata telah memengaruhi seluruh sendi kehidupan. Demikian juga sendi pendidikan tinggi, pelaksanaan Kuliah Kerja Nyata (KKN) harus dilaksanakan sesuai dengan anjuran pemerintah, work and school from home. Pelaksanaan KKN Covid - 19 Universitas Sebelas Maret (UNS) periode ini, dilaksanakan secara perorangan berlokasi dimana mahasiswa peserta KKN tinggal dengan tema besar kesehatan masyarakat, ketahanan pangan, ketahanan ekonomi masyarakat dan pendidikan selama pandemi Covid-19

Kelompok 75 terdiri dari 20 orang mahasiswa dari berbagai fakultas, sebaran lokasi KKN berada di Kabupaten Sukoharjo yang tersebar di berbagai Desa. Secara rinci, sebaran peserta KKN dapat dilihat dalam Tabel 1 danl Gambar 1. sebagai berikut:

Tabel 1. Sebaran Kelompok 75 KKN Covid 19

\begin{tabular}{|c|c|c|}
\hline Jenis Kelamin & Lokasi & Asal Fakultas \\
\hline 15 perempuan & Kabupaten Sukoharjo. & Keguruan dan IImu \\
\hline 5 laki-laki & $\begin{array}{l}\text { Kecamatan: Sukoharjo, Mojolaban, } \\
\text { Polokarto, Tawangsari, Gatak, Baki, } \\
\text { Kartasura, }\end{array}$ & $\begin{array}{l}\text { Pendidikan, Matematika } \\
\text { dan Ilmu Pengetahuan } \\
\text { Alam, Teknik }\end{array}$ \\
\hline
\end{tabular}

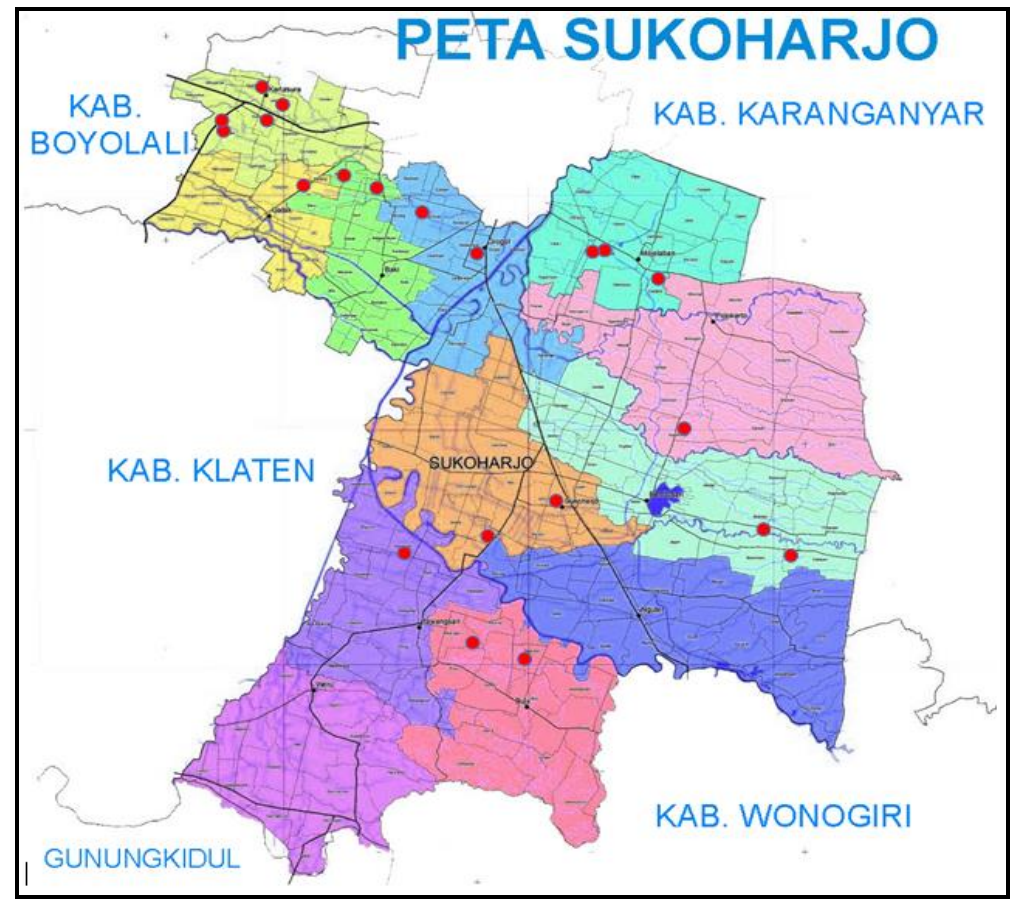

Gambar 1. Sebaran Lokasi Mahasiswa KKN Covid 19 Kelompok 75 
Sebaran peserta KKN yang begitu luas seiring dengan tingkat literasi digital mengenai wabah covid menjadi kelemahan yang muncul dalam pelaksanaan KKN ini. Pemahaman dasar masyarakat dalam memahami upaya pencegahan Covid-19 terutama social distancing memang sangat memerlukan kerjasama peserta KKN, perangkat desa, pemuda dan masyarakat sekitar untuk meningkatkan kesadaran pentingnya menjaga diri.

Selain mengatasi masalah diatas dibutuhkan kesadaran dalam menjaga kebersihan dan menjalankan upaya pencegahan virus Corona karena hal ini memiliki peran yang sangat besar dalam mengatasi wabah Covid-19 (dr. Kevin Adrian, 2020), untuk itu program kerja yang dilakukan peserta KKN kelompok 75 tidak terbatas pada upaya pencegahan berupa solialisasi saja, namun juga mengarah kepada pemberian bantuan tepat guna dan pembelajaran sesuai dengan kebutuhan yang ada. Sebaran program kerja kelompok 75, dapat dilihat pada tabel 2 berikut ini:

Tabel 2. Sebaran Program Kerja Literasi Digital KKN Covid-19 Kelompok 75

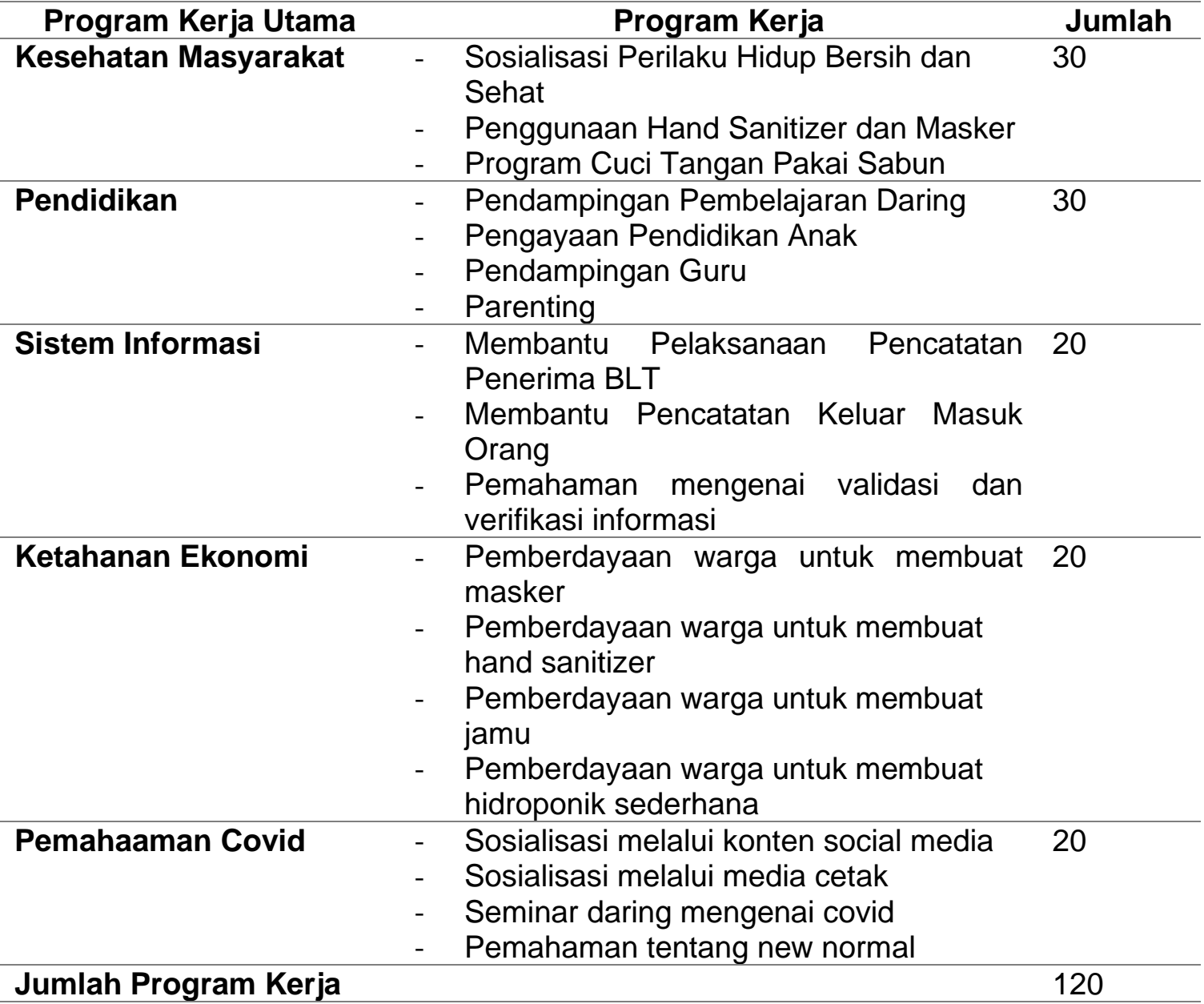

Keseluruhan program kerja mandiri tersebut selesai selama 45 hari pelaksanaan program KKN. Sebagian kegiatan dilakukan secara kolaboratif, dengan melibatkan antar anggota kelompok, luar kelompok, pemerintah desa, masyarakat sekitar, kolega ataupun relasi terkait dengan tema dan tujuan program kerja.

Capaian pengetahuan (knowledge) yang hendak dicapai yaitu meningkatkan literasi digital masyarakat mengenai penggunaan media social yang baik, benar dan bijak dilakukan dengan memanfaatkan keluasan platform media yang ada khususnya mengenai penyebaran dan pengananan wabah covid-19. Penyaringan informasi yang 
tepat dan penyebarkan informasi yang benar menjadi titik tumpu pelaksanaan program.

Perubahan social berupa perbaikan sikap (attitude) ditengarai dengan perubahan sikap masyarakat mengenai kewaspadaan penyebaran wabah covid-19 yang menjadi lebih waspada, tidak panik dan gegabah serta lebih berhati-hati untuk memahami dan menyebarkan berita terkait wabah covid-19

Sedangkan perubahan perilaku (practice) masyarakat tercapai dengan semakin luasanya penggunaan social media yang baik yang diikuti dengan penggunaan masker, melakukan tindakan jaga jarak dan menghindari kumpulan orang. Masyarakat pun dengan sukarela dan senang hati mengajak orang lain di sekitar mereka untuk melaksanakan tata laksana perilaku new-normal.

Kolaborasi ini juga dilakukan antar peserta KKN, misalnya seminar online. Kegiatan ini melibatkan beberapa peserta KKN dari wilayah yang berbeda untuk mengikuti dan melaksanakan program kerja secara bersama. Salah satu program kerja yang dilakukan oleh 3 orang anggota kelompok yaitu: Novita Ayuk Pratiwi, mahasiswi Prodi Pendidikan Ekonomi, bekerja sama dengan Puji Nur Ekowati, mahasiswi Prodi Pendidikan Pancasila dan Kewarganegaraan, dan Sania Al-Khoiriyah Umuri (Prodi Pendidikan Anak Usia Dini) Fakultas Keguruan dan IImu Pendidikan (FKIP) UNS.

Mengedepankan protokol kesehatan dan himbauan physical distancing, kelompok kecil mahasiswa ini merancang dan mengadakan forum diskusi online melalui whatsapp grup dengan judul "Melindungi Keluarga dari Penularan Covid-19", menghadirkan narasumber: Aprilya Setyawati, S.KM - Lulusan Terbaik Fakultas Kesehatan Masyarakat Universitas Indonesia; Juara 1 Pekan Ilmiah Mahasiswa Nasional (PIMNAS) IPB Bogor; Pengusaha Muda Bimbel "GEMILANG"; Admin Grup Kesehatan "BIKUM". Hadir sebagai narasumber dalam diskusi online ini Riris Nur M, S. Tr. Keb Alumni Kebidanan UGM dan Pengusaha muda "Seafood Cobek" dan "RD Rajut". Kegiatan berlangsung interaktif diikuti oleh pelajar, mahasiswa, anggota karang taruna, dan tim penggerak PKK di lingkungan Kecamatan Mojolaban, Kabupaten Sukoharjo. Mendapatkan sambutan yang meriah dan apresiasi tinggi dari pemerintah desa setempat atas inisiatif kegiatan yang positif dan membawa pengaruh baik terkait kondisi terkini.

Program kerja lain yang dilakukan anggota Kelompok 75 sangat berkaitan erat dengan peningkatan pemahaman dan keselamatan masa pandemi ini, terbukti dengan pemahaman masyarakat semakin meningkat (dibuktikan dengan perilaku tidak panik, tindakan rasional, dan mulai waspada dengan penyebaran virus COVID-19), masyarakat mempraktikkan cara membuat fasilitas kesehatan dan menjaga pola hidup bersih dan sehat, menginisiasi pembuatan masker dan disinfektan secara mandiri dan yang paling penting adalah penerapkan protokol kesehatan yang dianjurkan pemerintah (seperti physical distancing dan menggunakan masker saat keluar rumah).

Capaian program kerja individu yang dirancang mandiri dapat dilaksanakan bersamaan dengan kegitaan dari peserta lain. Pembuatan konten video untuk media social juga menjadi ajang kolaborasi. Peserta satu dengan yang lain, saling bahu membahu membuat konten, rekaman, editing dan penyebaran melalui Instagram, youtube, facebook dan media online lainnya.

Secara spesifik, kegiatan yang bertujuan utama untuk meningkatkan kolaborasi antar tim KKN yang berada pada lokasi yang berdekatan, untuk saling berbagi potensi dan kompetensi dalam memberikan pengaruh positif yang lebih besar untuk kebermanfaatan masyarakat sekitar berhasil dilaksanakan. Kolaborasi yang merupakan inti dari KKN secara umum berbuah baik. Pelaksanaan program 45 hari dapat berjalan dengan lancar atas bimbingan online yang intensif dari Dosen Pembimbing Lapangan, dukungan warga yang merasakan keberadaan mahasiswa KKN UNS secara langsung, dan pihak-pihak terkait lainnya yang selalu mengedepankan protokol kesehatan dan keselamatan dalam pelaksanaan program. 


\section{SIMPULAN}

Program KKN merupakan tempat pengabdian bagi masyarakat kepada masyarakat, melalui program ini mahasiswa juga belajar berbaur dan bersosialisasi kepada masyarakat. KKN pada tahun dilaksanakan sebagai bentuk tanggap wabah Covid-19 sehingga mahasiswa diharapkan mampu berperan dan berpartisipasi secara aktif membantu masyarakat di tengah masa pandemi.

Dari kegiatan yang telah dilakukan, dapat disimpulkan bahwa dengan adanya kolaborasi seperti yang dilakukan oleh Tim KKN UNS kelompok 75 telah berhasil memberikan kontribusi yang signifikan, khususnya bagi para warga yang mendapatkan pengetahuan dan pemahaman baru tentang internet cerdas, kreatif, dan produktif.

Keberhasilan kolaborasi antar kelompok atau tim KKN, dapat dicapai dengan adanya komunikasi yang baik antar kelompok, dilanjutkan dengan kerjasama untuk memetakan permasalahan yang muncul di lapangan, dan memberikan alternatif pemecahan masalah yang solutif dan implementatif. Hal lain yang dapat ditarik dari kegiatan ini adalah muncul dan terpupuknya semangat bergotong royong dan bahu membahu dalam memberikan kontribusi positif dalam program KKN secara keseluruhan. Kegiatan KKN juga dapat dilaksanakan tidak hanya berfokus pada desa yang ditempati, akan tetapi memungkinan untuk melintasi batas wilayah desa demi terselesaikannya masalah yang krusial di lokasi lain dengan efektif dan efisien.

\section{DAFTAR PUSTAKA}

Abdulsyani. (1994). Sosiologi Skematika, Teori, dan Terapan. Jakarta: Bumi Aksara.

Colbry, S., College, C., \& Adair, R. (2014). Collaboration Theory. The Journal of Leadership Education, 13(14), 63-75. doi:10.12806/V13/14/C8

Dijck, J. v., \& Poell, T. (2013). Understanding Social Media Logic. Media and Communication, 1(1), 2 - 14. doi:DOI: 10.12924/mac2013.01010002

Kaplan, A., \& Haenlein, M. (2010). Users of the world, unite! The challenges and opportunities of Social Media. Business Horizons, 53, 59 - 68. doi:doi:10.1016/j.bushor.2009.09.003

Muleme, J., Kankya, C., Ssempebwa, J. C., Mazeri, S., \& Muwonge, A. (2017). A Framework for Integrating Qualitative and Quantitative Data in Knowledge, Attitude, and Practice Studies: A Case Study of Pesticide Usage in Eastern Uganda. Frointiers in Public Health, 5, 1 - 15.

Roucek, J. S., \& Warren, R. L. (1964). Sociology, An Introduction. . New Jersey: Littlefield, Adams \& Co. 